\title{
Augmented Reality Objek Wisata Bogor Menggunakan Algoritma Lucas Kanade dengan Metode Marker Based Tracking
}

\author{
Fikry Ali Sya'dani, M Iwan Wahyuddin, Winarsih* \\ Fakultas Teknologi Komunikasi dan Informatika, Program Studi Informatika, Universitas Nasional, Jakarta, Indonesia \\ Email: ${ }^{1}$ pikryaly4@gmail.com, ${ }^{2}$ iwan_wyd@yahoo.com, ${ }^{3,}{ }^{*}$ wina@ unas.ac.id \\ Email Penulis Korespondensi: wina@unas.ac.id
}

\begin{abstract}
Abstrak-Teknologi informasi saat ini, sangat berkembang dan mudah ditemukan. Terutama dalam informasi objek wisata Bogor seperti Istana Bogor, Tugu Kujang, dan Stadion Pakansari. Namun data informasi yang dimiliki tidak sepenuhnya valid. Karena banyak wisatawan memperoleh data yang tidak cocok, karena minimnya informasi yang diperoleh. Oleh karena itu peneliti mencoba membuat aplikasi "Objek Wisata di Bogor" berbasis android dengan menggunakan teknologi Augmented Reality (AR) dan Algoritma Lucas Kanade, serta Marker Based Tracking upaya untuk mempermudah mendapakan informasi yang diinginkan pariwisata. Bogor merupakan salah satu kota di Provinsi Jawa Barat yang menarik banyak wisatawan terutama wisatawan domestik. Namun masih banyak tempat wisata di Bogor yang Masih banyak tempat wisata yang belum dikunjungi dan masih belum banyak diketahui oleh wisatawan. Sampai saat ini, peneliti mencoba membuat aplikasi "Objek Wisata di Bogor" berbasis android agar parawisatawan mengetahui bentuk objek dan informasi seperti Istana Bogor, Tugu Kujang, dan Stadion Pakansari. Menggunakan teknologi Augmented Reality (AR), teknologi itu sendiri memiliki foto, suara, dan objek 3d yang dapat membawa objek 3d virtual ke dunia nyata. Aplikasi Aplikasi "Objek Wisata di Bogor" menggunakan Android Studio, Unity, Sketchup, Vuforia, dan Visual Studio. Agar memudahkan wisatawan dalam mengidentifikasi data tempat wisata yang ingin dikunjungi. Aplikasi "Objek Wisata di Bogor" berfungsi untuk berbagi informasi data bagi wisatawan lokal maupun mancanegara, karena hal ini menjadi peluang bagi Pemerintah Daerah Bogor untuk meningkatkan pelayanan dan fasilitas di Bogor, sehingga wisatawan merasa aman tiba dan berkunjung di Bogor.
\end{abstract}

Kata Kunci: Bogor; Wisata; Augmented Reality; Algoritma Lucas Kanade; Metode Marker Based Tracking; Obje 3D

Abstract-Information technology today, is very developed and easy to find. Especially in information on Bogor tourist attractions such as the Bogor Palace, Tugu Kujang, and Pakansari Stadium. However, the data information held is not completely valid. Because many tourists get data that is not suitable, due to the lack of information obtained. Therefore, the researchers tried to make an android-based "Tourism Object in Bogor" application using Augmented Reality (AR) technology and the Lucas Kanade Algorithm, as well as Marker Based Tracking efforts to make it easier to get the information desired by tourism. Bogor is one of the cities in West Java Province that attracts many tourists, especially domestic tourists. However, there are still many tourist attractions in Bogor that are still many tourist attractions that have not been visited and are still not widely known by tourists. Until now, researchers have tried to make an android-based "Tourism Object in Bogor" application so that tourists know the shape of objects and information such as the Bogor Palace, Tugu Kujang, and Pakansari Stadium. Using Augmented Reality (AR) technology, the technology itself has photos, sounds, and 3d objects that can bring virtual 3d objects into the real world. The "Tourism Object in Bogor" application uses Android Studio, Unity, Sketchup, Vuforia, and Visual Studio. In order to make it easier for tourists to identify data on tourist attractions they want to visit. The application "Tourism Objects in Bogor" serves to share data information for local and foreign tourists, because this is an opportunity for the Bogor Regional Government to improve services and facilities in Bogor, so that tourists feel safe arriving and visiting Bogor.

Keywords: Bogor; Tourism; Augmented Reality; Lucas Kanade Algorithm; Marker Based Tracking Method; 3D Objects

\section{PENDAHULUAN}

Pariwisata merupakan aspek penting untuk ekonomi di Indonesia, industri pariwisata Indonesia menempati peringkat keempat dalam pendapatan anggaran 2015. Informasi yang diperoleh (BPS) Badan Pusat Statistik menegaskan bahwa minyak dan gas bumi (32.633) menempati urutan pertama, disusul oleh batubara (24.501), kelapa sawit (15.839), serta total wisatawan sebanyak 10.054. Informasi menunjukkan bahwa pariwisata ialah salah satu aspek yang menolong peningkatan anggaran negara. Zona yang mempunyai kemampuan sangat besar buat kenaikan pemasukan negeri serta wilayah kala dikelola dengan baik merupakan zona pariwisata[1]. Turis menjadi salah satu industri terbanyak di dunia pada saat ini. Bagi World Travel and Tourism Council, zona pariwisata ialah salah satu zona yang hadapi perkembangan yang lumayan besar, ialah 4 persen per tahun serta turut menyumbang lebih kurang 11, 6 persen dari GDP dunia[2] Bogor ialah wilayah dengan banyak tempat wisata, sehingga turis lokal pada weekend. jadi salah satu wilayah yang sangat diminati oleh turis. Bogor dinobatkan sebagai 10 besar dalam Indeks Pariwisata Indonesia 2016 oleh Departemen Pariwisata Indonesia. Bogor mempunyai objek wisata seperti ( alam, budaya serta buatan), sehingga jumlah destinasi wisata terus menjadi meningkat[3].

Aplikasi ini memakai teknologi Augmented Reality yang bekerja dengan metode memperlihatkan marker di dunia nyata secara real time setelah itu mencampurkan objek virtual dengan marker yang interaktif secara real time setelah itu ditampilkan lewat kamera smartphone[4]. Aplikasi ini memakai algoritma Lucas Kanade yang digunakan buat mengetahui marker pada objek 2D sehingga bisa menunjukkan objek 3D yang sama semacam pada riset tadinya yang bertajuk Implementasi Augmented Reality buat Pengenalan Bangunan Memiliki di Kab. Brass memakai algoritma Lucas Kanade[5]. Aplikasi Obyek Wisata Bogor ini pula memakai Tata cara Marker 
Based Tracking. Riset tadinya pula melaksanakan riset dengan judul Augmented Reality Recognition Huruf serta Angka Arab Memakai Tata cara Marker Based Tracking Berbasis Android, yang bertujuan buat mengenalkan pendidikan lewat media novel yang mereka hasilkan hijaiyah huruf, angka Arab serta alfabet memakai augmented reality pada kanak- kanak[6].

\section{METODOLOGI PENELITIAN}

\subsection{Augmented Reality (AR)}

Augmented Reality $(A R)$ ialah suatu teknologi yang menggambungkan objek 2 dimensi atau objek 3 dimensi ke dalam gambar pada marker dan kemudian memproyeksikan objek visual objek $3 \mathrm{~d}$ secara langsung. AR sangat berguna dalam meningkatkan proses belajar dan minat belajar siswa karena AR sendiri dapat meningkatkan keinginan Peserta Belajar sambil belajar dan bermain Proyeksi dengan sungguh-sungguh Melibatkan interaksi panca indera Peserta didik menggunakan teknologi AR ini. Hal ini dikarenakan AR memiliki fitur dan kegunaan yang hampir sama. sebaliknya. dengan media edukasi Digunakan untuk menyampaikan informasi [7] Augmented Reality juga berfungsi sebagai media data wisata untuk menarik perhatian wisatawan baik wisatawan domestik maupun mancanegara, serta untuk berbagi pengalaman dan bimbingan yang berbeda dalam menguasai setiap tempat atau daya tarik wisata yang dikunjungi [8]-[15].

\subsection{Algoritma Lucas Kanade}

Algoritma Lucas Kanade berfungsi sebagai pelacakan objek 3D pada ukuran yang berhasil muncul ketika penanda ditemukan. Objek ini dapat melacak pergerakan marker karena Algoritma Lucas Kanade memiliki keunggulan dalam mengetahui transformasi titik-titik citra seperti rotasi dan indentasi. Algoritma Lucas Kanade menunjukkan kumpulan titik-titik pada foto yang berubah dari posisi awal saat foto dipindahkan atau diubah (penskalaan, translasi, dan juga rotasi).

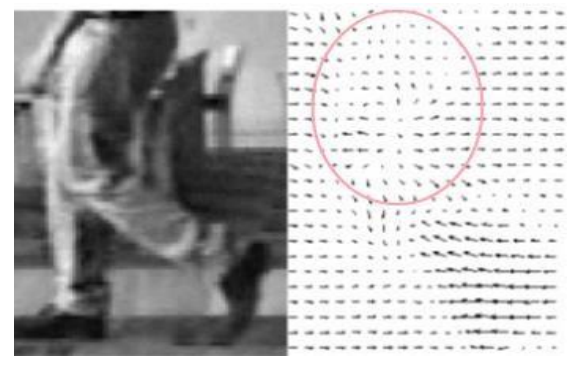

Gambar 1. Contoh titik citra bergerak

Lucas Kanade ada pada library Vuforia Engine. Vuforia berperan buat mencirikan titik citra yang digunakan selaku marker. Ada titik citra yang sudah ditemukan, Vuforia hendak berikan rating mutu pada foto, terus menjadi unik foto hingga titik citra hendak terus menjadi banyak serta rating yang ditampilkan oleh Vuforia hendak terus menjadi besar. Interval evaluasi Vuforia ialah 0- 5 dimana 0 ialah nilai terendah serta 5 ialah nilai tertinggi[16].

\subsection{Metode Marker based Tracking}

Metode Marker based Tracking ialah metode pendeteksian augmented reality (AR) yang menggunakan marker atau objek dua dimensi yang memiliki pola atau titik yang dilacak oleh sistem dan dibaca oleh laptop atau komputer melalui webcam, dan menghubungkan kamera ke laptop, atau komputer, biasanya marker atau objek memiliki ilustrasi hitam putih dengan background putih dan border hitam tebal (seperti barcode).

Di bawah ini adalah media marker yang telah dicetak untuk mempermudah memunculkan objek 3D pada aplikasi tempat wisata di Bogor pada penelitian ini.

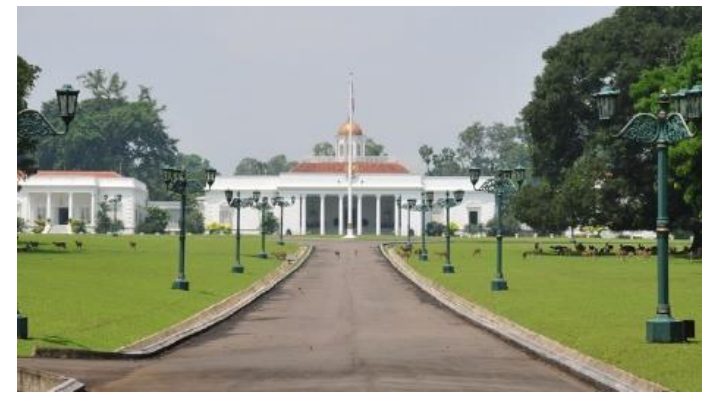

Gambar 2. Marker untuk objek istana bogor 
ISSN 2614-5278 (media cetak), ISSN 2548-8368 (media online)

Available Online at https://ejurnal.stmik-budidarma.ac.id/index.php/mib DOI 10.30865/mib.v5i3.3088

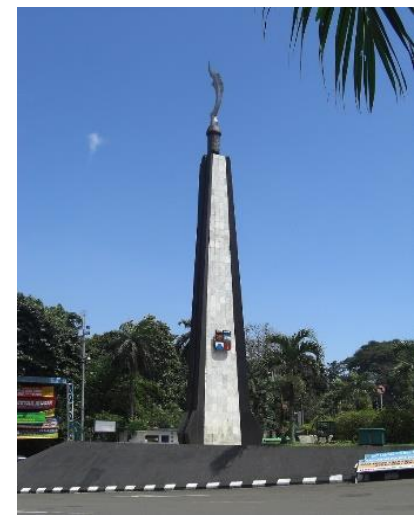

Gambar 3. Marker untuk objek tugu kujang

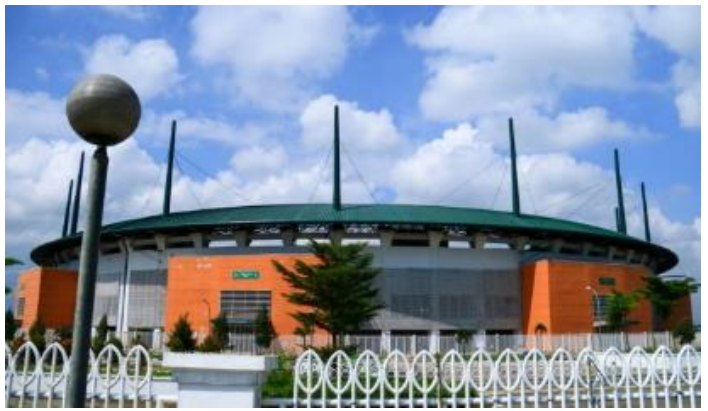

Gambar 4. Marker untuk objek stadion pakansari

Marker ialah salah satu faktor penting untuk sistem teknologi Augmented Reality (AR) untuk menciptakan objek virtual 3D ada marker[17]

\subsection{Kebutuhan Sistem}

Sebagai pendukung penerapan Augmented Reality Objek Wisata Bogor tentunya membutuhkan fitur yang cukup memadai, baik dari sisi aplikasi (fitur software) maupun dari sisi perangkat keras (hard features). Analisis kebutuhan peralatan yang digunakan untuk menjalankan simulasi ini adalah :

Tabel 1. Spesifikasi Hadware

\begin{tabular}{cc}
\hline Perangkat & Spesifikasi \\
\hline Prosesor & Core i3 $2,4 \mathrm{Ghz}$ \\
RAM & $10 \mathrm{~GB}$ \\
SSD & $120 \mathrm{~GB}$ \\
\hline
\end{tabular}

Tabel 2. Spesifikasi kebutuhan Software

\begin{tabular}{ll}
\hline \multicolumn{1}{c}{ Perangkat } & \multicolumn{1}{c}{ Fungsi } \\
\hline Windows 10 64-bit & $\begin{array}{l}\text { Sistem operasi yang digunakan dalam perencanaan aplikasi. } \\
\text { adalah software game engine yang dibuat untuk membuat aplikasi. "Objek wisata } \\
\text { Unity 2018.4.33f1 (64 bit) } \\
\text { bogor “ software ini bisa dijalankan di sistem operasi windows, linux \& mac-os. } \\
\text { Vuforia SDK }\end{array}$ \\
$\begin{array}{l}\text { Sebagai SDK (Application Development Kit), dalam pengembangan aplikasi } \\
\text { Augmented Reality digunakan untuk menyimpan marker untuk dibaca pada Unity.. } \\
2017\end{array}$ & $\begin{array}{l}\text { Software untuk membuat source code bahasa pemrograman C\# untuk aplikasi } \\
\text { Objek Wisata Bogor }\end{array}$ \\
\hline
\end{tabular}

\section{HASIL DAN PEMBAHASAN}

\subsection{Rancangan Flowchart Aplikasi}

Berikut ini adalah flowchart pada aplikasi Objek Wisata Bogor. 
ISSN 2614-5278 (media cetak), ISSN 2548-8368 (media online)

Available Online at https://ejurnal.stmik-budidarma.ac.id/index.php/mib DOI 10.30865/mib.v5i3.3088

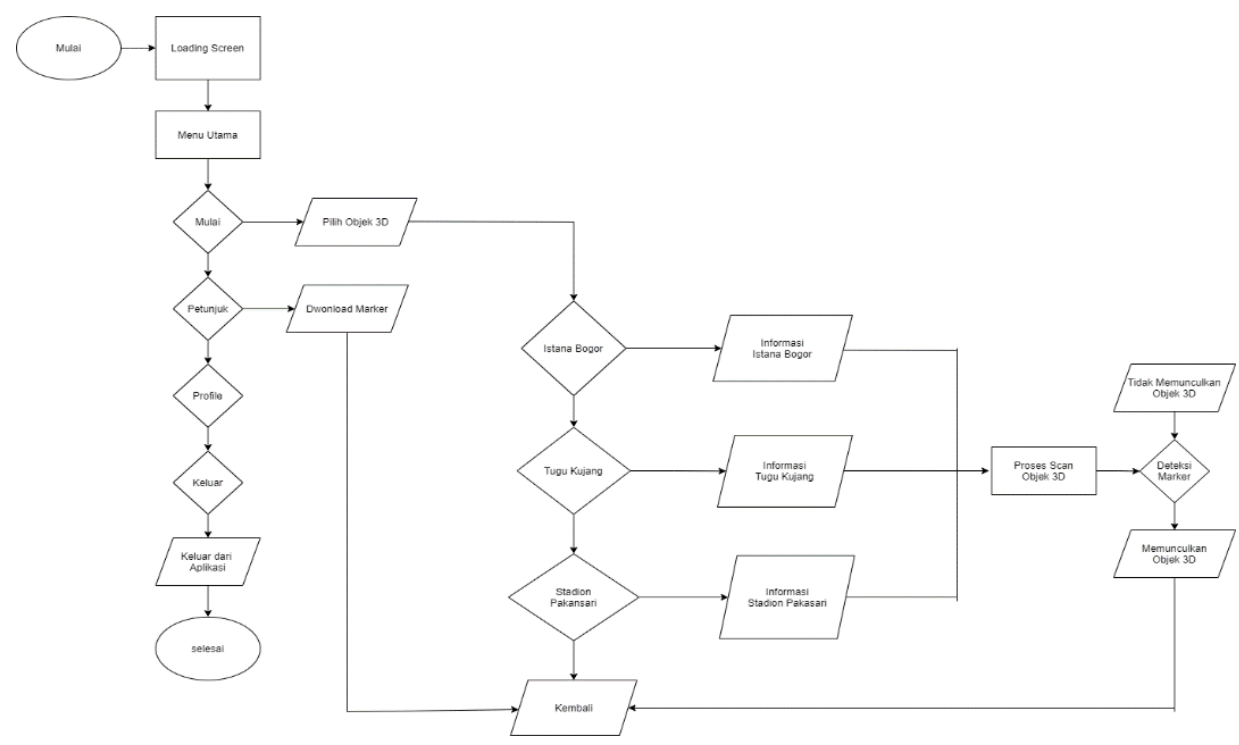

Gambar 5. Flowchart

\subsection{Implementasi Program}

Berikut pada tabel 3 merupakan tampilan GUI dari aplikasi program yang berhasil di rancang.

Tabel 3. GUI aplikasi

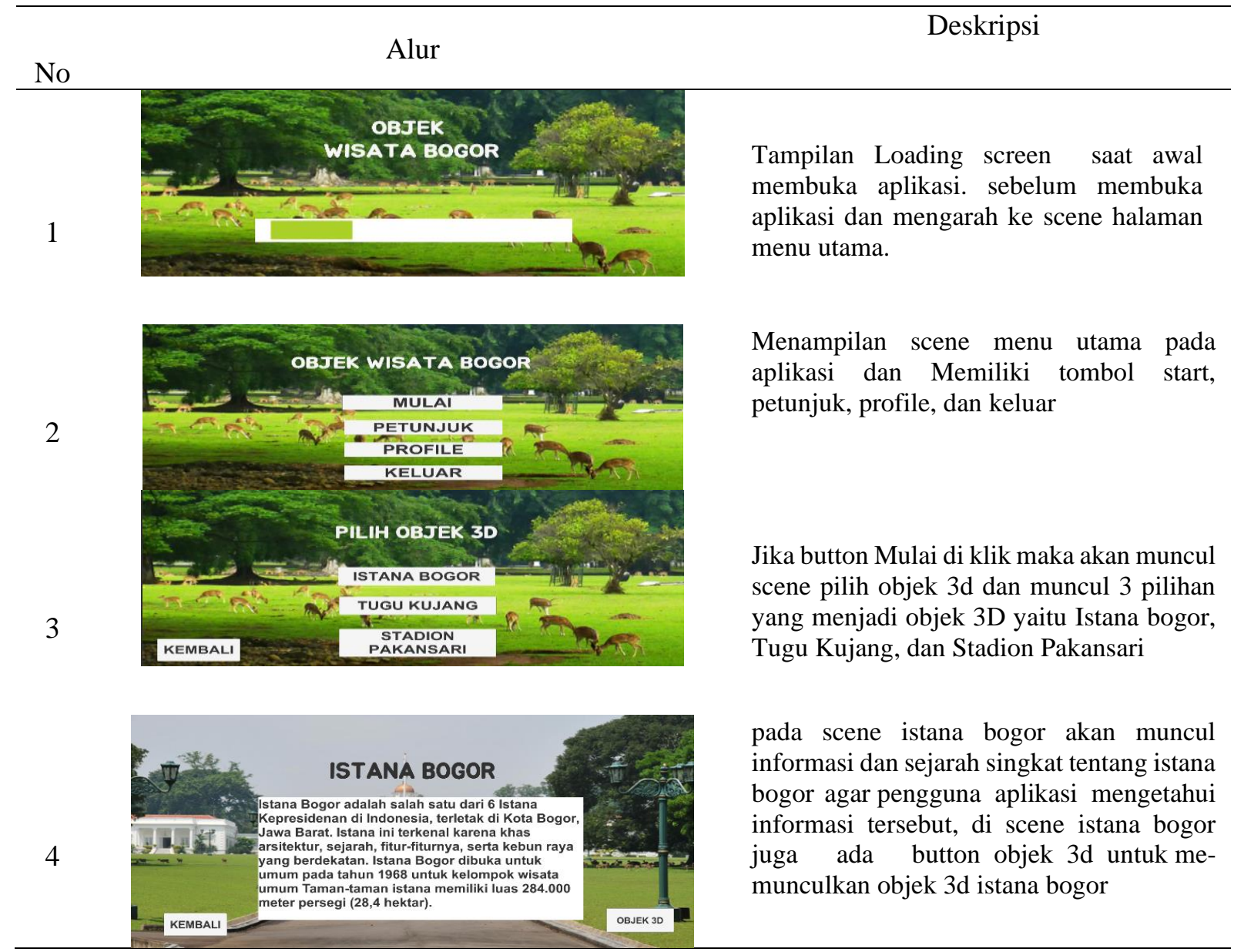




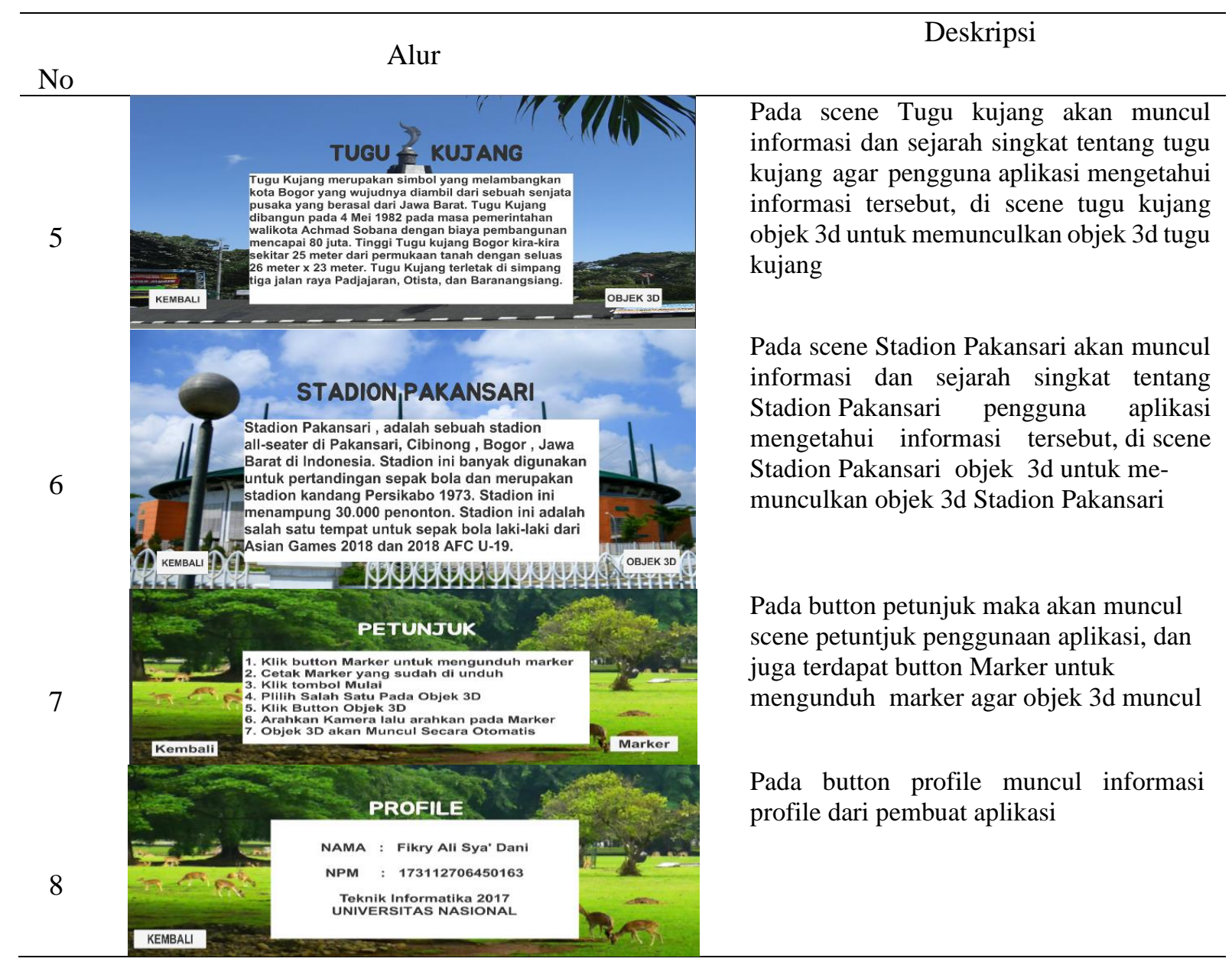

\subsection{Marker dan Hasil Objek 3D}

Berdasarkan penerapan dari algoritma Lucas Kanade dengan metode Marker Based Tracking maka didapatkan hasil seperti terlihat pada tabel 4 .

Tabel 4. Marker dan Hasil 3D

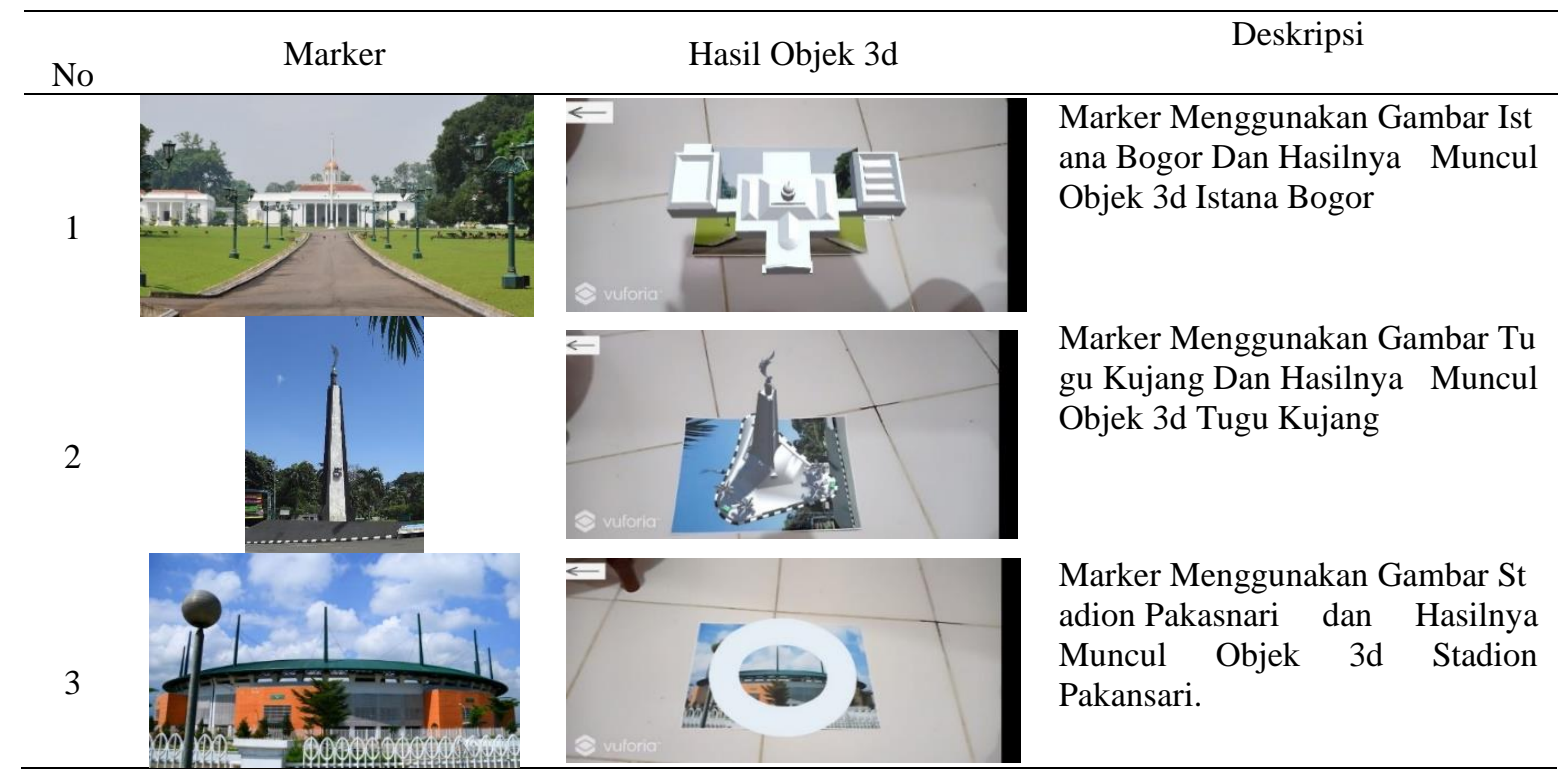

\subsection{Pengujian Sistem}

\section{a. Perangkat yang digunakan}

Pada Pengujian aplikasi Augmented Reality Objek Wisata Bogor telah dilakukan beberapa pengujian terhadap berbagai perangkat smartphone android untuk menganalisis pembandingan dan hasil aplikasi, dari versi android 
ISSN 2614-5278 (media cetak), ISSN 2548-8368 (media online)

Available Online at https://ejurnal.stmik-budidarma.ac.id/index.php/mib DOI 10.30865/mib.v5i3.3088

dan kamera. Kemudian pengetesan pada fungsionalitas aplikasi dengan menggunakan jarak kamera mendeteksi terhadap marker, pengetesan pada perangkat yang digunakan dengan memakai 3 tipe. Smartphone android yang berbeda ialah Xiaomi Redmi Note 9 (Android 10), Samsung Note 8 (Pie 9. 0), dan Xiaomi Redmi Note 7 (Android 10) sebagai berikut :

Tabel 5. Perangkat Pengujian

\begin{tabular}{cc}
\hline Perangkat & Versi Android \\
\hline Xiaomi Redmi Note 9 & 10 (Andorid) \\
Samsung Note 8 & 9.0 (Versi Pie) \\
Xiaomi Redmi Note 7 & 10 Android) \\
\hline
\end{tabular}

b. Pengetesan pada jarak

Pengujian jarak yang dicoba pada 3 fitur smartphone Android menampilkan hasil ialah jarak 10 CM, 20 CM, 30 CM, 40 CM serta 50 CM. sehingga marker bisa mengetahui objek.

Tabel 6. Pengujian Jarak

\begin{tabular}{ccc}
\hline Jarak cm & Versi pada Android & Keterangan \\
\hline \multirow{2}{*}{$10 \mathrm{~cm}$} & 10 (Android) & \\
& 9.0 (Versi Pie) & Terdeteksi \\
& 10 (Android) & \\
$20 \mathrm{~cm}$ & 9.0 (Android) & Terdeteksi \\
& 10 (Android) & \\
& 10 (Android) & Terdeteksi \\
$30 \mathrm{~cm}$ & 9.0 (Versi Pie) & \\
& 10 (Android) & Terdeteksi \\
& 10 (Android) & \\
$40 \mathrm{~cm}$ & 9.0 (Versi Pie) & Terdeteksi \\
& 10 (Android) & \\
\hline \multirow{2}{*}{$50 \mathrm{~cm}$} & 9.0 (Android) & (Andri Pie) \\
\end{tabular}

\section{c. Pengujian sudut kemiringan}

Tes kemiringan dengan Sudut $<15^{\circ}$ tidak terdeteksi pada 3 smartphone, karena intensitas cahaya pada sudut terlalu besar, sehingga pengetesan dengan sudut $21^{\circ}-60^{\circ}$ dapat dibaca pada tiga perangkat Android yang berbeda Kemudian tampilkan hasil yang sama pada tiga perangkat smartphone android dengan sudut $61^{\circ}-90^{\circ}$ agar objek dapat terdeteksi pada marker, dan pada sudut $80^{\circ}-90^{\circ}$ terlihat objek $3 \mathrm{D}$ dengan sempurna

Tabel 7. Pengujian sudut kemiringan Xiaomi Note 9

\begin{tabular}{ccc}
\hline Versi Android & Kemiringan & Keterangan \\
\hline & $0^{\circ}$ & Tidak Terdeteksi \\
& $10^{\circ}$ & \\
Xiaomi Redmi Note & $30^{\circ}$ & \\
9 & $40^{\circ}$ & \\
( Android 10 ) & $50^{\circ}$ & Terdeteksi \\
& $60^{\circ}$ & \\
& $70^{\circ}$ & \\
& $80^{\circ}$ & \\
& $90^{\circ}$ & \\
\hline
\end{tabular}

Tabel 8. Pengujian sudut kemiringan Samsung Note 8

\begin{tabular}{ccc}
\hline Versi Android & Kemiringan & Keterangan \\
\hline Samsung & $0^{\circ}$ & \\
Note 8 & $10^{\circ}$ & Tidak Terdeteksi \\
( Versi Pie 9.0) & $20^{\circ}$ & \\
& $30^{\circ}$ & \\
& $40^{\circ}$ & \\
\hline
\end{tabular}




\begin{tabular}{ccc}
\hline $50^{\circ}$ & Terdeteksi \\
$60^{\circ}$ & \\
$70^{\circ}$ & \\
$80^{\circ}$ & \\
$90^{\circ}$ & \\
\hline
\end{tabular}

Tabel 9. Pengujian sudut kemiringan Redmi Note 7

\begin{tabular}{ccc}
\hline Versi Android & Kemiringan & Keterangan \\
\hline & $0^{\circ}$ & Tidak \\
& & Terdeteksi \\
Xiaomi Redmi & $10^{\circ}$ & \\
& $20^{\circ}$ & \\
Note 7 & $30^{\circ}$ & Terdeteksi \\
& $40^{\circ}$ & \\
( Android 10 ) & $50^{\circ}$ & \\
& $60^{\circ}$ & \\
& $70^{\circ}$ & \\
& $80^{\circ}$ & \\
\hline
\end{tabular}

\section{d. Pengujian Fungsional Scene Aplikasi}

Tabel 10. Pengujian Fungsional Aplikasi

\begin{tabular}{llc}
\hline \multicolumn{1}{c}{ Scene } & \multicolumn{1}{c}{ Scene \& Hasil Menu Uji } & \multicolumn{1}{c}{ Fungsi } \\
& \multicolumn{1}{c}{ Hasil } \\
\hline Masuk Loading Screen & Sistem Berhasil Menampilkan Loading & {$[\sqrt{ }]$ Berhasil } \\
& screen & [] Gagal \\
Masuk Aplikasi Menu Utama & Sistem Berhasil Menampilkan tiga pilihan & {$[\sqrt{ }]$ Berhasil } \\
& Object 3D & {[] Gagal } \\
Memilih Object 3D Aplikasi & Tampilan Berhasil Menampilkan Object & {$[\sqrt{]}$ Berhasil } \\
& 3D Sesuai pilihan & {[] Gagal } \\
Memilih Menu Mulai Aplikasi & Sistem Berhasil Menampilkan menu mulai & {$[\sqrt{ }]$ Berhasil } \\
& & {[] Gagal } \\
Memilih Petunjuk Aplikasi & Sistem Berhasil Menampilkan Menu & {$[\sqrt{ }]$ Berhasil } \\
& petunjuk & {[] Gagal } \\
Memilih Menu Profile Aplikasi & Sistem Berhasil Menampilkan menu & {$[\sqrt{ }]$ Berhasil } \\
& profile & {[] Gagal } \\
Memilih Menu Keluar Aplikasi & Sistem Berhasil Menampilkan menu & {$[\sqrt{ }]$ Berhasil } \\
& keluar & {[] Gagal } \\
\hline
\end{tabular}

\section{KESIMPULAN}

Berdasarkan penelitian tentang Aplikasi Informasi Augmented Reality Objek Wisata di Bogor yang sudah berhasil dilakukan, dapat disimpulkan bahwa aplikasi data augmented reality tempat wisata di Bogor. di. Fungsi mobile Android dapat digunakan sebagai media data tempat wisata di Bogor, dan digunakan untuk mengidentifikasi media data historis bangunan seperti Istana Bogor, Sungai Tugugu dan Stadion Pakansari. Model sabuk. Objek 3D, dibuat menggunakan aplikasi Unity, Vuforia SDK, Sketchup, Draw io dan Figma sebagai alat. Uji coba aplikasi Obyek Wisata di Bogor, telah dicoba di 3 smartphone Android dengan jarak kamera tertentu. Dan sudut kemiringan, setelah itu aplikasi akan bekerja. Dengan Jarak minimum yang diuji ialah $10 \mathrm{~cm}$ sampai $50 \mathrm{~cm}$. Sudut kemiringan android rendah, dan kemiringan tidak terlihat hingga $30^{\circ}$ hingga $0^{\circ}$. Dengan menggunakan aplikasi augmented reality berbasis android ini, anda dapat menampilkan tempat wisata Bogor secara 3D sehingga dapat anda perkenalkan kepada masyarakat luas. Aplikasi ini dapat lebih menarik masyarakat untuk mengenal tempat wisata di Bogor karena ditampilkan secara 3D. Algoritma Lucas Kanade dapat digunakan untuk mendeteksi marker pada objek 2D untuk menampilkan objek 3D. Deteksi marker menggunakan algoritma lucas kanade melalui tahapan pengabuan citra 2D dari warna kemudian ditentukan titik pikselnya untuk mencari tepi citra/citra melalui teknik sobel. Cari titik kunci hingga akhirnya menemukan titik piksel untuk penanda yang diterapkan pada gambar 2D. 
ISSN 2614-5278 (media cetak), ISSN 2548-8368 (media online)

Available Online at https://ejurnal.stmik-budidarma.ac.id/index.php/mib DOI 10.30865/mib.v5i3.3088

\section{REFERENCES}

[1] R. Permana, H. Andrianof, and R. Afira, "Augmented Reality (AR) Sarana Promosi Obyek Pariwisata Jam .Gadang.Bukittinggi dan Pantai Wisata Carocok Pesisir Selatan,” Indones. J. Comput. Sci., vol. 7, no. 2, pp. 129-142, 2018, doi: 10.33022/ijcs.v7i2.81.

[2] DAWAMI, Angga Kusuma. Perancangan Promosi Wisata Pendakian Gunung Merbabu melalui Desa Cuntel. Magenta| Official Journal STMK Trisakti, 2019, 3.1: 387-396.

[3] Rosiyanti, A. W., \& Susilowati, M. H. D. (2017, July). Perkembangan Objek Wisata di Kabupaten Bogor. In Prosiding Industrial Research Workshop.and National Seminar (Vol. 8, pp. 462-469).

[4] I. G. N. D. P. Yohanes Priyo Atmojo, "Pemanfaatan Augmented Reality Pada Sistem Informasi Geografis Kampus Di Bali,” P. 2, 2014.

[5] Maitsa, Elsa, Tito Sugiharto, and Yati Nurhayati. "IMPLEMENTASI AUGMENTED REALITY UNTUK PENGENALAN GEDUNG BERSEJARAH DI KAB. KUNINGAN MENGGUNAKAN ALGORITMA LUCAS KANADE." Buffer Informatika 6.2 (2020).

[6] A. A. Wahid and H. F. Mulany, "Penerapan Augmented Reality Pada Aplikasi Pembelajaran pancasila," no. July, pp. 06, 2019.

[7] MUSTAQIM, Ilmawan..Pemanfaatan.Augmented Reality sebagai media pembelajaran. Jurnal Pendidikan Teknologi dan Kejuruan, 2016, 13.2: 174-183.

[8] INTERAKTIF, PROMOSI TEMPAT WISATA YANG; WIDODO, RYANTANA NUR. IMPLEMENTASI AUGMENTED.REALITY SEBAGAI MEDIA.

[9] A. Ismayani, Membuat Sendiri Aplikasi Augmented Reality. Elex Media Komputindo, 2020.

[10] U. M. Ar, H. Wibawanto, and A. L. Nastiti, Panduan Lengkap: Membuat Game Augmented Reality(AR) dengan Unity 3D. Andi, 2019.

[11] A. K. Pamoedji, Maryuni, and R. Sanjaya, Mudah Membuat Game Augmented Reality (AR) dan Virtual Reality (VR) dengan Unity 3D. Elex Media Komputindo, 2019.

[12] Trunfio, Mariapina, et al. " Menginovasi model layanan museum warisan budaya melalui virtual reality dan augmented reality: dampak pada pengalaman dan kepuasan wisatawan secara keseluruhan. "Majalah Wisata Warisan" (2020): 1-19.

[13] R. Palmarini, J. A. Erkoyuncu, R. Roy, and H. Torabmostaedi, "A systematic review of augmented reality applications in maintenance," Robot. Comput. Integr. Manuf., vol. 49, no. March 2017, pp. 215-228, 2018.

[14] S. Ternier, R. Klemke, M. Kalz, and M. Specht, “ARLearn: Augmented Reality Meets Augmented Virtuality,” J. Univers. Comput. Sci., vol. 18, no. 15, pp. 2143-2164, 2012.

[15] D. Nincarean, M. B. Alia, N. D. A. Halim, and M. H. A. Rahman, "Mobile Augmented Reality: The Potential for Education," Procedia - Soc. Behav. Sci., vol. 103, pp. 657-664, 2013.

[16] Setyawan, Risyan Arief, and Afdhol Dzikri.."Analisis penggunaan metode marker tracking pada augmented reality alat musik tradisional jawa tengah." Simetris: Jurnal Teknik Mesin, Elektro dan Ilmu Komputer 7.1 (2016): 295-304.

[17] Maitsa, Elsa, Tito Sugiharto, and Yati Nurhayati. "IMPLEMENTASI AUGMENTED REALITY UNTUK PENGENALAN GEDUNG BERSEJARAH DI KAB. KUNINGAN MENGGUNAKAN ALGORITMA LUCAS KANADE." Buffer Informatika 6.2 (2020): 6-15. 